\title{
Rule of Structural Factors in Formation of Porphyry Copper Deposits in South Western Part of Kerman Area, Iran
}

\author{
Hasan Alizadeh1, Mehran Arian²* \\ ${ }^{1}$ Faculty of Science, Department of Geology, Payame Noor University, Tehran, Iran \\ ${ }^{2}$ Department of Geology, Science and Research Branch, Islamic Azad University, Tehran, Iran \\ Email: ${ }^{*}$ mehranarian@yahoo.com
}

Received 28 May 2015; accepted 17 July 2015; published 20 July 2015

Copyright (C) 2015 by authors and Scientific Research Publishing Inc.

This work is licensed under the Creative Commons Attribution International License (CC BY). http://creativecommons.org/licenses/by/4.0/

c) (i) Open Access

\begin{abstract}
Kerman area is located in southern parts of central Iranian volcanic belt. The area under study is located in the southern part of this complex copper mineralization in the area, which is mainly porphyry type and is associated with extensive hydrothermal alteration. This area has a great potential as far as tertiary porphyry copper deposits are concerned. To the exploration of porphyry copper deposits in study area, we have analyzed the lineaments. The lineaments interpreted out from ETM + (band8) data is recognized as another method for locating porphyry type copper mineralization. There is a close correlation between photo lineament factor values and the known copper mineralization in the area. The relationship between 16 porphyry copper deposits with faults and fractures in the area is studied. Photo lineament factor assessments by using satellite photos indicate a strong relationship between a number of lineation intersection in each cell refer to an amount of average lineation in whole map (c/C ratio). In the study area, ratio of $\mathrm{c} / \mathrm{C}$ even has more relationship refers to $\mathrm{PF}$ factor that has previously described in the papers.
\end{abstract}

\section{Keywords}

Porphyry Copper Deposit, Tectonics, Copper, c/C Ratio, Faults, Iran

\section{Introduction}

Formation of Porphyry Copper deposits are related to magmatic and hydrothermal process [1]. In a mineralization province, a number of lineations and fractures can be a key for exploration, because these fractures can

\footnotetext{
"Corresponding author.
}

How to cite this paper: Alizadeh, H. and Arian, M. (2015) Rule of Structural Factors in Formation of Porphyry Copper Deposits in South Western Part of Kerman Area, Iran. Open Journal of Geology, 5, 489-498. 
act as a conduit for moving of mineral content fluids. Fluids mostly move from high pressure areas towards low pressure and low temperature areas. At this case magmatic fluids instead of concentrating, spread more [2].

Faults, fractures, shear zones and different spatial stresses concentrate magma or move it toward shallow parts of the crust [3]. Study of geometries and faults which are linked with porphyry copper deposits, can be valuable for finding proper location of porphyry deposits [4]. Mineralization systems in volcano-plutonic belts of the earth are closely related to strike slip faults which have formed in these arcs [5].

This area belongs to Urmieh-Dokhtar province from physiographic-tectonic zoning map of Iran's sedimentary basins [6]. Dominant structural trend in Urmieh-Dokhtar province is NW-SE. From tectonics view, it contains a magmatic arc that is a result of subduction to beneath of southern active continental margin of Cimmerian plate. It has marked by widespread Eocene volcanism. Urmieh-Dokhtar province has continued to south of Black Sea and Its width has increased from Naien city that many parts have covered by quaternary deposits of Dagh Sorkh Kavir, Southern Urmieh Lake, Namak and Hoz-e Soltan Lakes have formed on it. So, there are a few backland basins with Playa type sedimentation because of dip decreasing in Benioff zone (in NW part of magmatic arc). SE part of magmatic arc has formed on southwest margin of East-Central Iran microcontinent. This area is a semi-active magmatic arc and based on previous work on the salt and mud diapirism [7]-[17] and neotectonic regime in Iran [18]-[23], Zagros in south Iran is the most active zone [24]-[43]. Then, Alborz [44]-[80] and Central Iran [81]-[95] have been situated in the next orders. Urmieh-Dokhtar volcano-plutonic zone is elongated from northwest toward southeast along major trust of Zagros (Figure 1). 11 porphyry copper deposits

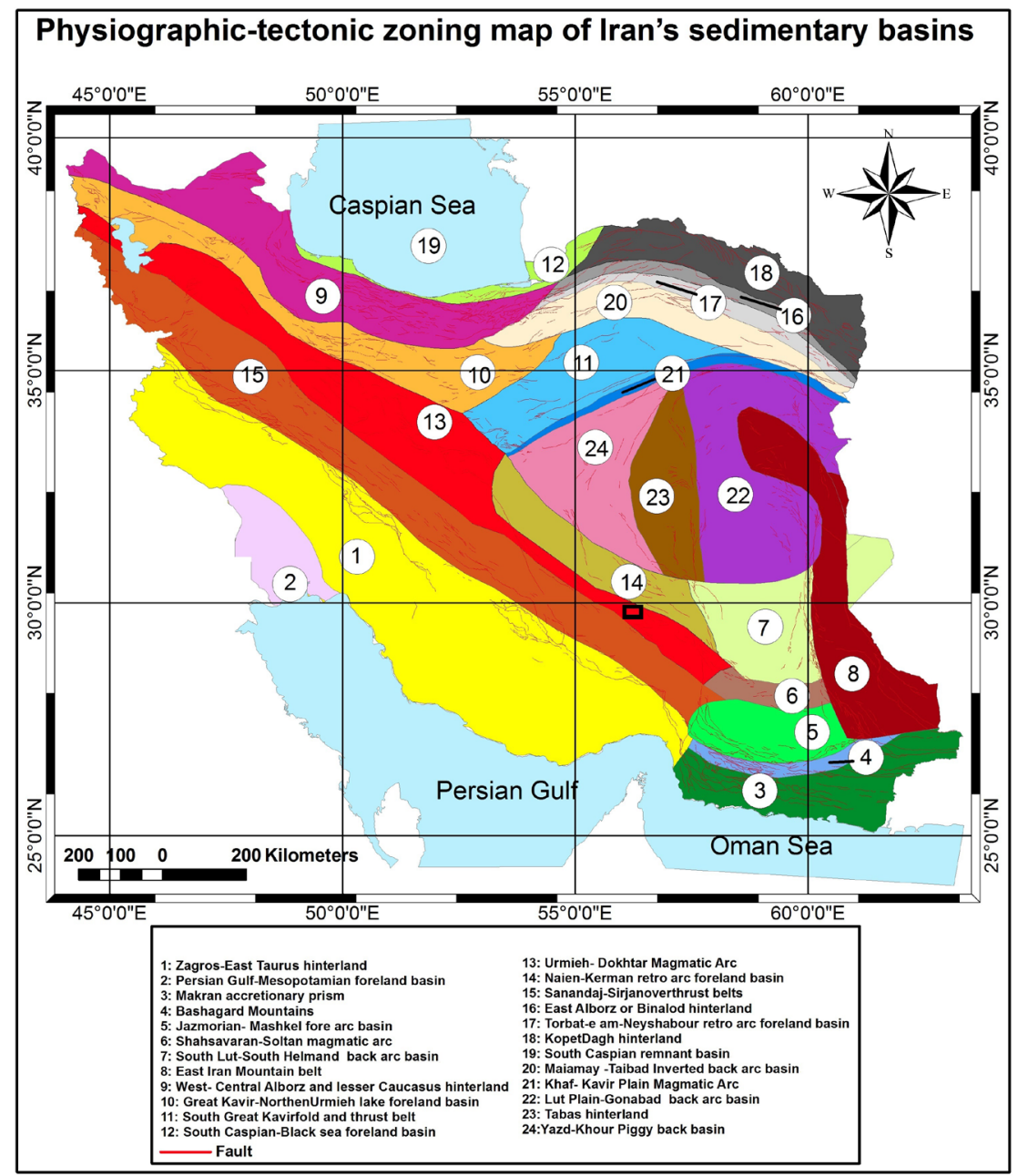

Figure 1. Physiographic-tectonic zoning map of Iran's sedimentary basins, modified from [1]. The study area is shown in the black rectangle. 
have known in this zone. In Kerman province in south of Iran, there is a sub tectonic zone named Dahaj-Sardoiyeh, northern parts of Dahaj-Sardoiyeh belt that is shown by black rectangle (Figure 1) study to determine the relationship between tectonic factors and porphyry copper deposits.

\section{Materials and Methods}

The study area is situated in the southern part of the central Iranian volcano-sedimentary complex, southwest of the Kerman province. There has been folding of Lower Tertiary volcano-sedimentary rocks and emplacement of Late Tertiary granodiorite, diorite, monzonite and tonalite in the volcano-sedimentary complex. A detailed description of the geology between the Rafsanjan Belt and Sirjan Belt, in which the study area is located, is given by [96].

The Eocene volcano-sedimentary rocks consist of trachybasalt and trachyandesitic tuffs, lava flows and porphyrites, trachyandesitic and trachybasaltic rocks, tuffaceoussediments, and andesitic and basaltic rocks. The sedimentary rocks in the volcanic sedimentary complex are mainly sandstone and, less frequently limestone. The intrusive rocks are granodiorite to tonalite. Most of the plutonic and volcanic rocks are hydrothermally altered and mineralized in places. Argillization, sericitization and propylitization are the most common types of hydrothermal alteration in the area. Cretaceous colored melange is the oldest and the Quaternary alluvial deposits and gravel fans are the youngest exposures in the study area. Cretaceous sediments are mainly flysch. Eocene volcanic rocks are subdivided into the Bahr-e-Aseman complex and the Lower Razak, Middle Razak and Upper Razak complexes. The study area has 16 porphyry copper deposits that are listed in Table 1.

Using [98] [99] models indicate good relationship between fractures with faults and lineations. Study area is strongly tectonized and fault systems cannot be categorized as a simple shear and should be divided into 4 trends:

1) Faults with east-west trend;

2) Faults with north east-south west trend;

3) Faults with north-south trend;

4) Faults with north west-south east trend.

Table 1. Location of porphyry copper deposits in the study area, adapted from [97].

\begin{tabular}{|c|c|c|c|}
\hline No & Name & $\mathbf{X}$ & $\mathbf{Y}$ \\
\hline 1 & Bagh-e Khoshk & 402412 & 3300391 \\
\hline 2 & Kooh Pang & 408559 & 3304491 \\
\hline 3 & Darrehzar & 393778 & 3306045 \\
\hline 4 & Hoseynabad & 379269 & 3307250 \\
\hline 5 & Noochoon & 389627 & 3310529 \\
\hline 6 & Sarkooh & 381705 & 3311711 \\
\hline 7 & Sarcheshmeh & 390593 & 3313497 \\
\hline 8 & Dehsiyahan & 403229 & 3318474 \\
\hline 9 & Abdar & 337013 & 3354344 \\
\hline 10 & Meydook & 323991 & 3366956 \\
\hline 11 & Sara & 321389 & 3370138 \\
\hline 12 & Kooh Sara & 319165 & 3371850 \\
\hline 13 & Sareno & 305780 & 3374456 \\
\hline 14 & Ijoo & 303352 & 3380325 \\
\hline 15 & Gode Koulivari & 307472 & 3386843 \\
\hline 16 & Keder & 285924 & 3389242 \\
\hline $\mathbf{x}, \mathbf{y}$ acc & ne $40 \mathrm{~N}$ & & \\
\hline
\end{tabular}


The oldest faults of the area have east-west trend and later faults with trend northeast-southwest trend, were created. The youngest faults of the area are north-south faults. The study area as a shear plain right lateral fault system is surrounded by Rafsanjan fault in the north and Shahr-e babak fault in the south [100]. These faults are strike slip with oblique vector. Fault-parallel contraction and fault-parallel simple shear are the most common faults in the area. As the first faults had east-west trend, thus shear was acted as fault-parallel contraction. After shifting stress trend, it has changed to fault-parallel simple shear. Fractures and lineations with using of some special filters were studied. The result is shown in Figure 2.

Using photo lineament factor (PF) for exploration of groundwater in fractured hard rock is common. Results of such techniques can be useful for exploration of porphyry deposits as well. Number of lineation, their length, and number of intersection of lineations can be used to analysis of these structural phenomena. [101] has introduced the following formula to calculate photo lineament factor:

$$
\mathrm{PF}=(\mathrm{a} / \mathrm{A})+(\mathrm{b} / \mathrm{B})+(\mathrm{c} / \mathrm{C})+(\mathrm{d} / \mathrm{D})
$$

where;

a: Number of lineation in each cell;

A: Average lineation in whole of the map;

b: Length of lineation in each cell;

B: Average number of lineations in whole of the map;

c: Number of lineation intersection in each cell;

C: Average number of lineation in whole of the map;

d: Number of trends in each cell;

D: Average number of trends in whole of the map.

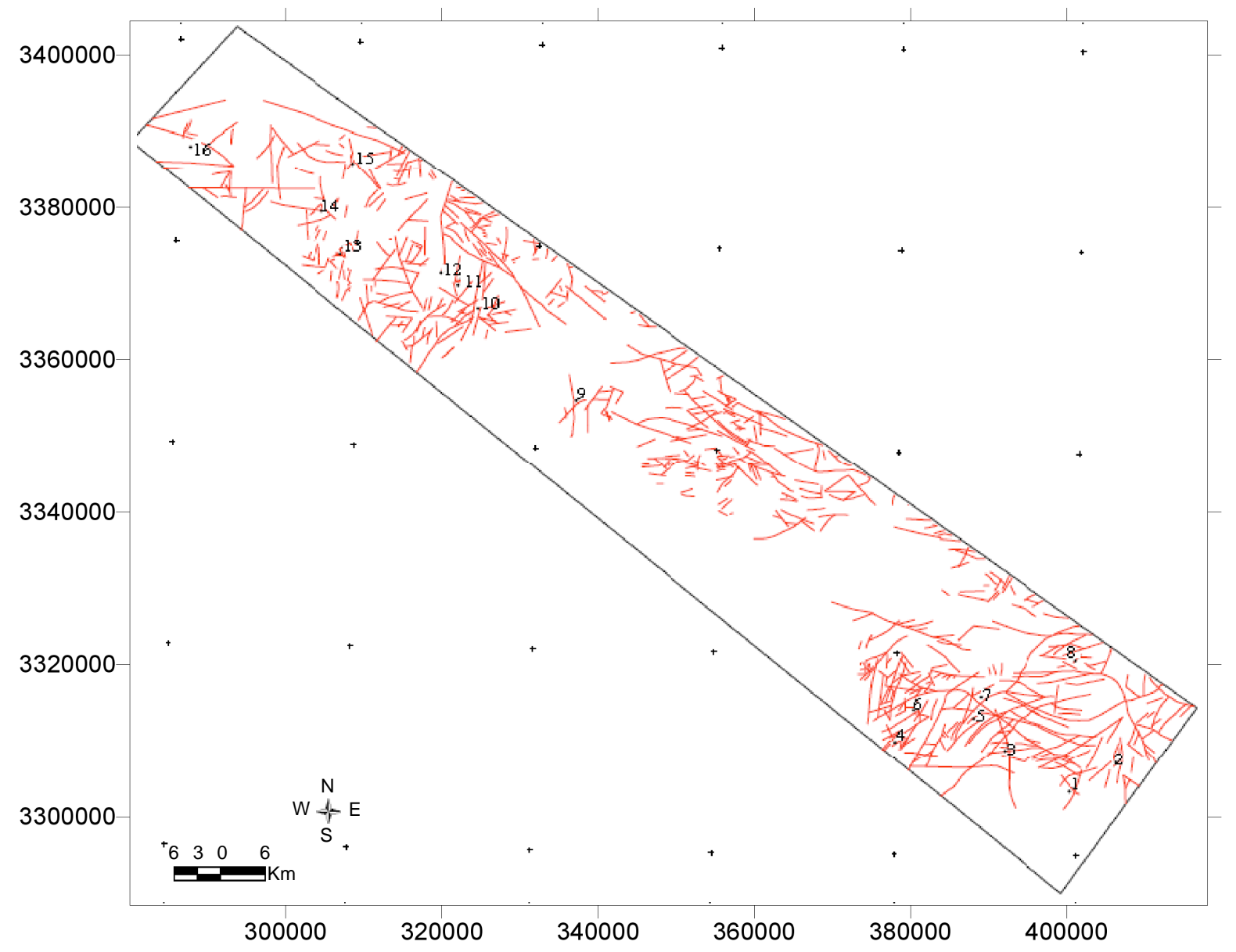

Figure 2. Map showing faults in the study area. Black points are porphyry copper deposits described in Table 1. 


\section{Results and Discussion}

Linear analysis of a $2 \times 2 \mathrm{~km}$ grid cell size for the intended study area and regional lineament map was implemented. The following parameters were determined in a separate cell in 1042. Photo lineament factor in the study area was calculated and drawn by using satellite photos and softwares like Surfer and ArcGIS.

With respect PF, Photo lineament factor was calculated in each cell (Figure 3).

The results show that there is strong relationship with location of porphyry copper deposits and PF. Also the area with high PF amount has coincidence with surface alteration manifestations

As can be seen in the map of the intersection of porphyry copper deposit formation lineaments an important role in fertility in the region. So as to adapt relatively well between the porphyry deposits in the region with the highest concentration of intersection in the region can be seen.

For a better result, different factors collaborated with distribution of porphyry copper deposits [102]-[104]. The results show that the ratio of $\mathrm{c} / \mathrm{C}$, in above mentioned formula, has better collaboration with the porphyry copper deposits even from PF (Figure 4). A recent study shows that the intersection of faults and fault can be multiple ways to create environments for the porphyry intrusive magmatic.

\section{Conclusion}

Local fractures are the major reason for transferring hydrothermal fluids towards the surface of the crust. As even in the area without surface alteration manifestations that has high amount of PF, porphyry copper deposits are visible. The intersection of strike slip faults forms the best location of concentration of hydrothermal fluids and this position has improved in the study area. In this study, spatial relationship between 16 copper porphyry deposits with faults and fractures of the study area has studied. The Strong relationship between lineament factor and location of porphyry deposits has deducted. The major propellant to transfer of mineralized hydrothermal fluids is smashed rocks and local fracturing. These fractures can create surface alterations as well as. Although in some



Figure 3. Contour map of PF distribution in the study area. 


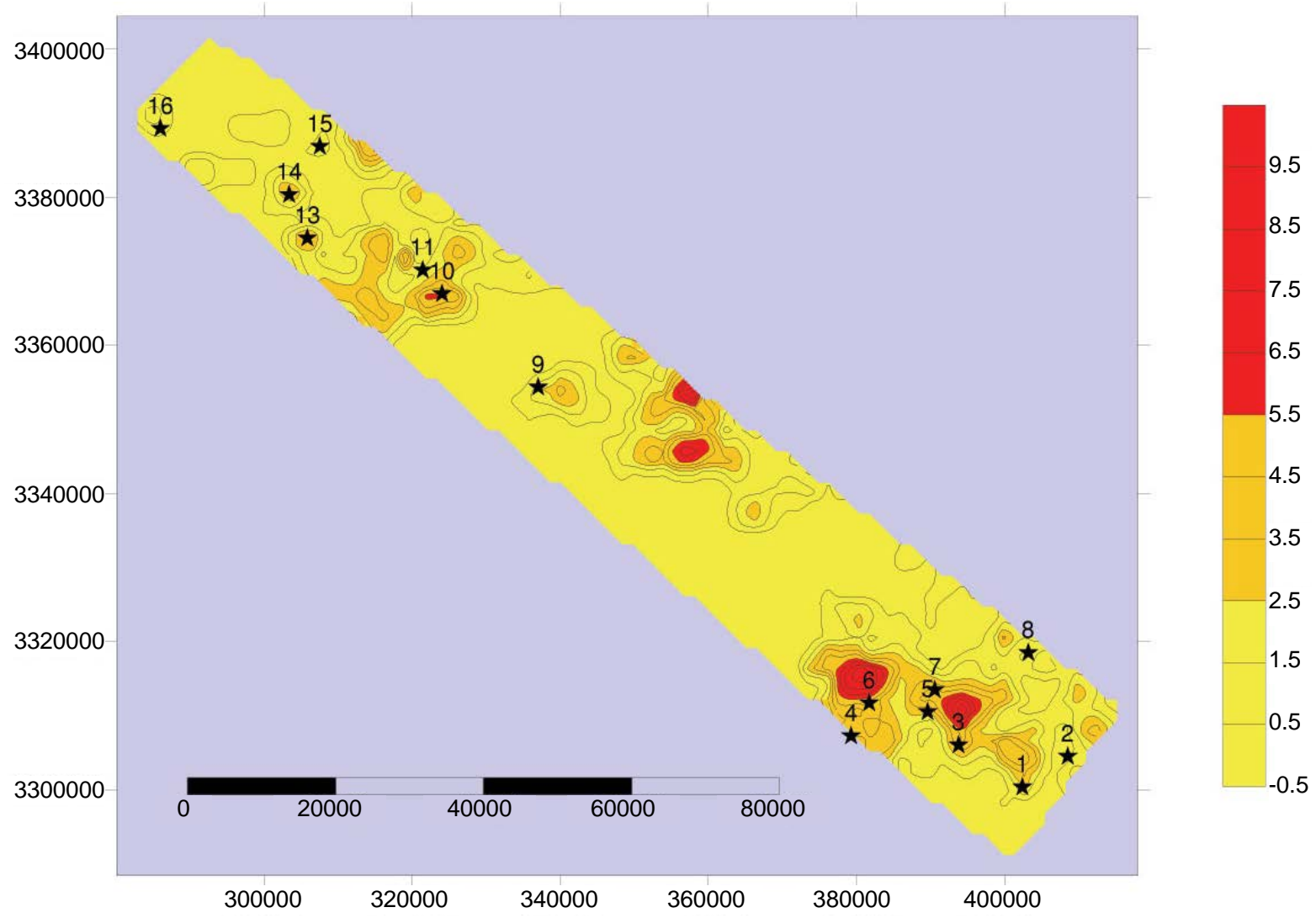

Figure 4. Contour map of c/C ratio distribution in the study area.

places with the lack of surface alteration and high photo-lineament factor, porphyry copper deposits are evidences. The relationship between numbers of lineation intersection in each cell refers to an amount of average lineation in a whole map (c/C ratio). In the study area, ratio of $\mathrm{c} / \mathrm{C}$ even has more relationship referring to $\mathrm{PF}$ factor that has previously described in the papers. A recent study shows that the intersection of faults or linements can be multiple ways to create environments for the porphyry intrusive magmatic.

\section{Acknowledgements}

This work has funded by the Department of Geology, Science and Research branch, Islamic Azad University, Tehran, Iran. Also, special thanks to vice-president for research in Science and Research branch, Tehran.

\section{References}

[1] Garza, R.A.P., Titley, S.R. and Pimentel, B.F. (2001) Geology If the Escondida Porphyry Copper Deposit, Antofagostaregion, Chile. Economic Geology, 96, 307-344. http://dx.doi.org/10.2113/gsecongeo.96.2.307

[2] Caranza, E.J.M. and Hale, M. (2002) Where Are Porphyry Copper Deposits Spatially Localized? A Case Study in Benguet Province, Philippines. Natural Resource Research, 11, 45-59. http://dx.doi.org/10.1023/A:1014287720379

[3] Ryan, P.D. and Dewey, J.F. (1990) A Geological and Tectonic Cross-Section of the Caledonides of Western Ireland. Journal of the Geological Society, 148, 173-180. http://dx.doi.org/10.1144/gsjgs.148.1.0173

[4] Zarasvandi, A., Liaghat, S. and Zentilli, M. (2005) Geology of the Darreh-Zerreshk and Ali-Abad Porphyry Copper Deposit, Central Iran. International Geology Reviews, 47, 620-646. http://dx.doi.org/10.2747/0020-6814.47.6.620

[5] Richards, J.P., Boyce, A.J. and Pringle, M.S. (2001) Geologic Evolution of the Escondida Area, Northern Chile: A Model and Temporal Localization of Porphyry Cu Mineralization. Economic Geology, 98, 1515-1513. http://dx.doi.org/10.2113/gsecongeo.98.8.1515

[6] Arian, M. (2013) Physiographic-Tectonic Zoning of Iran’s Sedimentary Basins. Open Journal of Geology, 3, $169-177$. http://dx.doi.org/10.4236/ojg.2013.33020 
[7] Arian, M. (2011) A Preface on Salt Diapirism of Iran. AsarNafis Press, Qum, 309 p.

[8] Arian, M. and Noroozpour, H. (2015) The Biggest Salt-Tongue Canopy of Central Iran. Open Journal of Geology, 5, 55-60. http://dx.doi.org/10.4236/ojg.2015.52005

[9] Asadian, F., Pourkermani, M. and Arian, M. (2007) Tectonic Geomorphology of Salt Structures in the GarmsarLasjerd Area. Geographical Research, 39, 75-84.

[10] Pourkermani, M. and Arian, M. (1997) Salt Domes of Central Iran. Journal of Humanities, 3, 29-41.

[11] Arian, M. (2012) Salt Diapirism and Tectonics. 2nd Edition, AsarNafis Press, Qum, 319 p.

[12] Arian, M. and Noroozpour, H. (2015) Tectonic Geomorphology of Iran's Salt Structures. Open Journal of Geology, 5, 61-72. http://dx.doi.org/10.4236/ojg.2015.52006

[13] Asadian, F. and Arian, M. (2009) Identification of Diapiric Provinces of Central Iran through Geological and Geographical Analysis. International Journal of Agriculture Environment \& Biotechnology, 2, 3443-3451.

[14] Arian, M. (2012) Clustering of Diapiric Provinces in the Central Iran Basin. Carbonates and Evaporites, 27, 9-18. http://dx.doi.org/10.1007/s13146-011-0079-9

[15] Pourkermani, M. and Arian, M. (1998) Tectonic Geomorphology of Salt Domes in West of Zanjan Province, Iran. Geographical Research, 47, 44-53.

[16] Arian, M. and Feizi, F. (2010) The Significance of Faulting on the Surficial Spreading of Evaporitic Deposits in the Varamin-Semnan Area. Journal of Earth and Resources, 3, 1-20.

[17] Feizi, F., Arian, M. and Arian, A. (2015) Mud Diapirism on the Makran, Iran: Case Study on the Napag Mud Volcano. Open Journal of Geology, 5, 300-308. http://dx.doi.org/10.4236/ojg.2015.55027

[18] Arian, M. and Khodabakhshnezhad, A. (2015) Sedimentary Environments Can Be Changed by Geotechnology (Case Study: A Morphotectonic Idea for Design of Extensive Artificial Bay on the Iranian Plateau). International Journal of Geosciences, 6, 487-496. http://dx.doi.org/10.4236/ijg.2015.65039

[19] Arian, M. (2011) Middle East Tectonics. AsarNafis Press, Qum, 236 p.

[20] Arian, M. (2010) Applied Seismotectonics. Farazamin Press, Tehran, 304 p.

[21] Arian, M. and Maleki, R. (2008) Neotectonics. Farazamin Research Center, Tehran, 150.

[22] Pourkermani, M. and Arian, M. (1998) Seismicity of Iran. Shahid Beheshti University Press, Tehran, 212.

[23] Pourkermani, M. and Arian, M. (1997) Seismotectonics. Dez Ab Consulting Engineers Company Press, Tehran, 270.

[24] Arian, M. and Aram, Z. (2014) Relative Tectonic Activity Classification in the Kermanshah Area, Western Iran. Solid Earth, 5, 1277-1291. http://dx.doi.org/10.5194/se-5-1277-2014

[25] Mashal, M., Pour Kermani, M., Charchi, A., Almasian, M. and Arian, M. (2013) Pattern of Structural Geology Underground in Eastern of North Dezfol Embayment. Advances in Environmental Biology, 7, 260-268.

[26] Pazhoohan, M., Arian, M., Ghorashi, M. and Khosrotehrani, K. (2014) A Study of Drainage Pattern Responses to Active Tectonics in Tadvan Region, SW Iran. Geodynamics, 1, 36-41.

[27] Rahimi, N. and Arian, M. (2014) Tectonic Geomorphplogy of Kangavar-Sosangerd Region, West Iran. Advances in Environmental Biology, 8, 119-124.

[28] Arian, M. and Hashemi, A. (2008) Seismotectonic Zoning in the Zagros. Journal of Sciences, 18, 63-76.

[29] Arian, M., Ahmadnia, A., Qorashi, M. and Pourkermani, M. (2002) Structural Analysis of Mengharak Transcurrent Fault System in Zagros, Iran. Special Geo 2002 Conference Issue Geoarabia, 7, 209-210.

[30] Arian, M., Qorashi, M., Pourkermani, M. and Ahmadnia, A. (2003) Fractal Analysis of Mengharak Transcurrent Fault System in Zagros, Iran. Abstracts of 4th International Conference on Seismology and Earthquake Engineering, Tehran, 12-14 May 2003, 23.

[31] Baharvand, S., Pourkermani, M., Ajalloian, R., Arian, M. and Nouryazdan, A.R. (2010) Seymareh Landslide and Its Role in Environmental and Geomorphologic Changes of the Pole-Dokhtar Area. Journal of the Earth, 4, 13-24.

[32] Abdideh, M., Qorashi, M., Rangzan, K. and Arian, M. (2011) Assessment of Relative Active Tectonics Using Morphometric Analysis, Case Study of Dez River (Southwestern, Iran). Geosciences, 20, 33-46.

[33] Arian, M., Qorashi, M., Pourkermani, M. and Ahmadnia, A. (2006) The Structural Significance Kareh Bas Transcurrent Fault System in the Zagros Fold and Thrust Belt. Geosciences, 15, 126-133.

[34] Arian, M. and Noroozpour, H. (2015) Seismic Activity and Fractal Geometry of Kareh Bas Fault System in Zagros, South of Iran. Open Journal of Geology, 5, 291-299. http://dx.doi.org/10.4236/ojg.2015.55026

[35] Ehsani, J. and Arian, M. (2015) Quantitative Analysis of Relative Tectonic Activity in the Jarahi-Hendijan Basin Area, Zagros Iran. Geosciences Journal, 19, 1-15. http://dx.doi.org/10.1007/s12303-015-0016-3 
[36] Arian, M., Qorashi, M. and Ahmadnia, A. (2003) Analysis of Behbahan Shear Zone. Iranian Journal of Geology, 1, 14.

[37] Baratpour, F., Arian,M. and Solgi, A. (2015) Geometric Analysis of Tukak and Kamarun Anticlines on Izeh Zone, Zagros. Geosciences, 24, 191-200.

[38] Arian, M., Ahmadipour, M.R. and Khodaei, K. (2003) The Elements of Fold Style in Soltananticline, Northeast of Pol-e Dokhtar. Iranian Journal of Geology, 1, 1-8.

[39] Omidali, M., Arian, M. and Sorbi, A. (2015) Neotectonics of Boroujerd Area, SW Iran by Index of Active Tectonics. Open Journal of Geology, 5, 309-324. http://dx.doi.org/10.4236/ojg.2015.55028

[40] Ehsani, J., Arian, M. and Ghorashi, M. (2015) Geomorphic Signatures of Active Tectonics in the Jarahi-Hendijan Drainage Basin in the South West Iran. Geosciences, 24, 211-218.

[41] Khodabakhshnezhad, A., Pourkermani, M., Arian, M., Matkan, A.A. and Charchi, A. (2015) Active Tectonics of Great Karoun River Basin. Geosciences, 24, 13-28.

[42] Maleki, Z., Arian, M., Solgi, A. and Ganjavian, M.A. (2015) Elements of Fold Style Analysis in the Karbasi Anticline, Interior Fars Region, Zagros. Geosciences, 24, 293-302.

[43] Arian, M. (2015) Seismotectonic-Geologic Hazards Zoning of Iran. Earth Sciences Research Journal, 19, 7-13.

[44] Alladin ,Y., Talebian, M., Arian, M. and Ahmadi, M.M. (2015) Geotechnical Investigation and Seismic Zonation of Alluvial Deposits in Western Tehran. Geosciences, 24, 333-342.

[45] Taherkhani, B., Nazari, H., Pourkermani, M. and Arian, M. (2015) Geometry and Recent Kinematics of the North Qazvin Fault: Morphotectonic Approach. Geosciences, 24, 29-38.

[46] Manuchehri, H., Arian, M., Ghorashi, M., Solgi, M. and Sorbi, A. (2015) Geomorphic Signatures of Active Tectonics in the Chalus Drainage Basin in the Alborz, Iran. Geosciences, 24, 273-280.

[47] Noroozpour, H., Arian, M. and Sorbi, A. (2015) Fault Movement Potentials in the Tehran-Semnan Region (North Iran). Open Journal of Geology, 5, 281-290. http://dx.doi.org/10.4236/ojg.2015.55025

[48] Arian, M., Maleki, Z. and Noroozpour, H. (2011) Cenozoic Diastrophism and Deformational Events in the East Central Alborz. Journal of Basic and Applied Scientific Research, 1, 2394-2400.

[49] Feizi, F., Arian, A. and Rahmani, R. (2007) Seismotectonic Zoning in the Eastern Part of the Central Alborz. Journal of Sciences, 17, 151-164.

[50] Khavari, R., Arian, M. and Ghorashi, M. (2009) Neotectonics of the South Central Alborz Drainage Basin, in NW Tehran, N Iran. Journal of Applied Sciences, 9, 4115-4126. http://dx.doi.org/10.3923/jas.2009.4115.4126

[51] Arian, M. and Bagha, N. (2012) Active Tectonics of Tehran Area, Iran. Journal of Basic and Applied Scientific Research, 2, 3805-3819.

[52] Bagha, N., Arian, M., Ghorashi, M., Pourkermani, M., El Hamdouni, R. and Solgi, A. (2014) Evaluation of Relative Tectonic Activity in the Tehran Basin, Central Alborz, Northern Iran. Geomorphology, 213, 66-87. http://dx.doi.org/10.1016/j.geomorph.2013.12.041

[53] Arian, M. and Feizi, F. (2005) Application of Geomorphic Indices to the Assessment of Relative Tectonic Activity Levels in the Alborz-Central Iran Border Zone. Journal of Sciences, 15, 378-403.

[54] Arian, M., Bagha, N., Khavari, R. and Noroozpour, H. (2012) Seismic Sources and Neo-Tectonics of Tehran Area (North Iran). Indian Journal of Science and Technology, 5, 2379-2383.

[55] Moghimi, H., Arian, M. and Sorbi, A. (2015) Fault Movement Potential of Marzanabad Area, North Alborz, Iran. Open Journal of Geology, 5, 126-135. http://dx.doi.org/10.4236/ojg.2015.53012

[56] Arian, M. and Pourkermani, M. (2004) Tectonic Elements of South Flank in the East-Central Alborz Mountain. Journal of Sciences (Teacher Training University), 4, 359-368.

[57] Arian, M. and Qorashi, M. (2006) The Movement Potential Evaluation of the Major Quaternary Faults in Alborz-Central Iran Border Zone, from the East of Tehran to the East of Semnan. Journal of Geosciences (Geological Survey of Iran), 15, 184-188.

[58] Poroohan, N., Pourkermani, M. and Arian, M. (2013) An Assessment of Relationship in F-Parameter and Paleostress Fields in Heterogeneous Lithologies: Roudbar Area (Northwest of Iran). Australian Journal of Basic \& Applied Sciences, 7, 933-942.

[59] Poroohan, N., Poukermani, M. and Arian, M. (2009) An Assessment on Correlations of Seismotectonic Parameters Preceding and Following Roudbar-Manjil Earthquake (Gilan, North of Iran). Australian Journal of Basic \& Applied Sciences, 3, 2643-2652.

[60] Farrokhnia, A.R., Pirasteh, S., Pourkermani, M. and Arian, M. (2011) Geo-Information Technology for Mass Wasting Hazard Zonation: Central-West Alborz-Iran. Disaster Advances, 4, 24-33. 
[61] Farrokhnia, A.R., Pirasteh, S., Pradhan, B., Pourkermani, M. and Arian, M. (2011) A Recent Scenario of Mass Wasting and Its Impact on the Transportation in Alborz Mountains, Iran Using Geo-Information Technology. Arabian Journal of Geosciences, 4, 1337-1349.

[62] Sorbi, A., Arian, M. and Pourkermani, M. (2009) The Movement Potential Evaluation of the Major Quaternary Faults in Tehran Quadrangle. Journal of the Earth, 19, 176-182.

[63] Feizi, F. and Arian, M. (2006) The Classification of Thrust Fronts in the Alborz-Central Iran Border Zone from the East of Varamin to the East of Semnan. Journal of Sciences, 16, 75-87.

[64] Arian, M. and Feizi, F. (2005) Application of Geomorphic Indices to the Assessment of Relative Tectonic Activity Levels in the Alborz-Central Iran Border Zone the Alborz-Central Iran Border Zone. Journal of Science, 15, 378-403.

[65] Arian, M. and Pourkermani, M. (2004) Structural Significance of North Semnan and Attary Faults in Alborz-Central Iran Border Zone. Journal of Science, 14, 4551-4569.

[66] Arian, M. and Pourkermani, M. (2005) Cenozoic Diastrophism and Deformational Events in the Southern Flank of Central-East Alborz. Journal of Faculty Earth Sciences, 10, 43-51.

[67] Arian, M., Pourkermani, M., Qorashi, M. and Ghasemi, M.R. (2003) North Semnan Fault System and Its Role on Basin Division. 8th Symposium of Geological Society of Iran, Shahrood, 4-6 September 2003, 11-17.

[68] Pourkermani, M. and Arian, M. (2001) Structural Geomorphology of Northeastern Kurdistan. Journal of Humanities, 7, 37-48.

[69] Mardani, Z., Ghorashi, M. and Arian, M. (2011) Geomorphic Signatures of Active Tectonics in the Talaghanrud, Shahrud and Sefidrud Drainage Basins in Central Alborz, N Iran. Geosciences, 20, 159-166.

[70] Sorbi, A., Arian, M. and Pourkermani, M. (2011) The Application of Geomorphic Indices to the Assessment of Relative Tectonic Activity Levels in Tehran Quadrangle. Journal of the Earth, 6, 1-9.

[71] Khavari, R., Ghorashi, M., Arian, M. and Khosrotehrani, K. (2010) Geomorphic Signatures of Active Tectonics in the Karaj Drainage Basin in South Central Alborz, N Iran. Geosciences, 19, 67-74.

[72] Mousavi, E.J. and Arian, M. (2015) Tectonic Geomorphology of Atrak River, NE Iran. Open Journal of Geology, 5, 106-114. http://dx.doi.org/10.4236/ojg.2015.53010

[73] Nouri, R., Jafari, M.R., Arian, M., Feizi, F. and Afzal, P. (2013) Correlation between Cu Mineralization and Major Faults Using Multifractal Modelling in the Tarom Area (NW Iran). Geologica Carpathica, 64, 409-416. http://dx.doi.org/10.2478/geoca-2013-0028

[74] Nouri, R., Jafari, M.R., Arian, M., Feizi, F. and Afzal, P. (2013) Prospection for Copper Mineralization with Contribution of Remote Sensing, Geochemical and Mineralographical Data in Abhar 1:100,000 Sheet, NW Iran. Archives of Mining Sciences, 58, 1071-1084. http://dx.doi.org/10.2478/amsc-2013-0074

[75] Nouri, R., Afzal, P., Arian, M., Jafari, M. and Feizi, F. (2013) Reconnaissance of Copper and Gold Mineralization Using Analytical Hierarchy Process in the Rudbar 1: 100,000 Map Sheet, Northwest Iran. Journal of Mining and Metallurgy, 49, 9-19.

[76] Arian, M. and Nouri, R. (2015) Lineament Tectonics and Mineralization in Tarom Area, North Iran. Open Journal of Geology, 5, 115-124. http://dx.doi.org/10.4236/ojg.2015.53011

[77] Feizi, F. and Arian, M. (2011) The Role of Structural Controllers in Geneses of Copper Deposits in 1:50,000 Map of Saiin Qaleh. Journal of Sciences, 21, 1-10.

[78] Khavari, R., Ghorashi, M. and Arian, M. (2009) Assessment of Relative Active Tectonics, South Central Alborz (North Iran). EGU General Assembly Conference Abstracts, 11, 1137.

[79] Bahiraee, S., Arian, M., Qorashi, M. and Solgi, M. (2015) The Movement Potential Evaluation of the Mosha Fault (the West of Firoozkuh to the Shahrestanak). Geosciences, 24, 123-126.

[80] Bagha, N., Ghorashi, M., Arian, M., Pourkermani, M. and Solgi, A. (2015) Neotectonic Analysis of Mosha-North Tehran Fault Zone, Based on Morphotectonic Features, Central Alborz, Northern Iran. Geosciences, 24, 41-52.

[81] Mosavi, E.J. and Arian, M. (2015) Neotectonics of Tabas Area, Central Iran by Index of Active Tectonics (IAT). Open Journal of Geology, 5, 209-223. http://dx.doi.org/10.4236/ojg.2015.54019

[82] Nazemi, M., Ghorashi, M., Ghassemi, M.R. and Arian, M. (2015) Morphotectonics Features of Alluvial Fans Associated with Active Tectonics (Shotori Mountains, East of Tabas-Central Iran). Geosciences, 24, 91-100.

[83] Daryani, N.J., Arian, M. and Omran, N.R. (2015) Tectonics and Mineralization of Copper in the Ardestan-Kahang Area, Central Iran by Remote Sensing. Open Journal of Geology, 5,188-196. http://dx.doi.org/10.4236/ojg.2015.54017

[84] Arian, M. and Pourkermani, M. (2001) Rivers Morphology and Active Tectonic(Reviewing the Current Status of Ghezel Ozon River in the Province of Zanjan). 5th Conference of Geological Society of Iran, Tehran, 28-30 August 2001, 556.

[85] Eshghi, Z., Arian, M. and Pourkermani, M. (2012) Structural Investigation on the Lak Mining Area (Bueen Zahra) 
Based on Remote Sensing, Used for Its Mineralization. Journal of the Earth, 6, 145-155.

[86] Arian, M., Toudeshki, V.H. and Noroozpour, H. (2011) Active Tectonics of Qezel Ozan River Basin, NW Iran. Journal of Applied Environmental and Biological Sciences, 1, 291-295.

[87] Alizadeh, H., Arian, M., Lotfi, M., Ghorashi, M. and Ghorbani, M. (2015) Determination of Porphyry Copper Deposit Locations Using Photo Lineament Factor in Northern Parts of the Dehaj-Sardoiyeh Belt. Geosciences, 24, $247-252$.

[88] Toudeshki, V.H., Pourkermani, M., Arian, M. and Khosrotehrani, K.H. (2011) Influence of Structures on the Ghezel Ozan River. Geosciences, 21, 55-60.

[89] Toudeshki, V.H. and Arian, M. (2011) Morphotectonic Analysis in the Ghezel Ozan River Basin, NW Iran. Journal of Geography and Geology, 3, 258-260.

[90] Pourkermani, M. and Arian, M. (1997) Salt Domes of Central Iran. Journal of Humanities, 3, 29-41.

[91] Arian, M., Pourkermani, M., Sistanipour, A. and Noroozpour, H. (2011) Kinematic Significance of Fold- and Fault-Related Fracture Systems in the Rafsanjan's Northeast Highlands (Central Iran). Journal of Basic and Applied Scientific Research, 1, 3398-3406.

[92] Arian, M., Pourkermani, M., Sistanipour, A. and Noroozpour, H. (2011) Seismicity and Fault Segmentation of BafqBaghin Fault System (Central Iran). Journal of Applied Environmental and Biological Sciences, 1, 382-396.

[93] Mosavi, E.J., Arian, M., Ghorashi, M. and Nazemi, M. (2012) Measurments of Geomorphic Indices in Tabasarea. Journal of the Earth, 7, 213-225.

[94] Arian, M. (2010) Earthquake-Fault Hazard Investigations in the Kerman Quadrangle. Journal of Sciences, 19, $176-182$.

[95] Pourkermani, M., Qorashi, M., Arian, M., Sorbi, A., Farokhnia, A. and Solgi, A. (2003) Structural Features in Western Part of the Lut Region. Iranian Journal of Geology, 1, 29-44.

[96] Dimitrijevic, M.D. (1973) Geology of Kerman Region. Geology Survey of Iran, Report No. 52, 334 p.

[97] Arian, M., Alizadeh, H. and Noroozpour, H. (2011) Satellite Geometry of Faults and Fractures and Its Relationship with Porphyry Deposits in Northern Parts of Dahaj-Sardoiyeh Belt, South of Iran. Indian Journal of Science and Technology, 4, 1303-1306.

[98] Swanson, M.T. (1988) Pseudotachylite-Bearing Strike-Slip Duplex Structures in the Fort Foster Brittle Zone, S. Maine. Journal of Structural Geology, 10, 813-828. http://dx.doi.org/10.1016/0191-8141(88)90097-1

[99] Storti, F., Rossetti, F., Läufer, A.L. and Salvini, F. (2006) Consistent Kinematic Architecture in the Damage Zones of Intraplate Strike-Slip Fault Systems in North Victoria Land, Antarctica and Implications for Fault Zone Evolution. Journal of Structural Geology, 28, 50-63. http://dx.doi.org/10.1016/j.jsg.2005.09.004

[100] Walker, R.T. (2006) A Remote Sensing Study of Active Folding and Faulting in Southern Kerman Province. S.E. Iran. Journal of Structural Geology, 28, 654-668. http://dx.doi.org/10.1016/j.jsg.2005.12.014

[101] Hardcastle, K.C. (1995) Photolineament Factor: A New Computer-Aided Method for Remotely Sensing the Degree to Which Bedrock Is Fractured. Photogrammetric Engineering Remote Sensing, 61, 739-747.

[102] Qorashi, M. and Arian, M. (2011) Tectonics of Iran. Geologic Survey of Iran, Tehran, 336 p.

[103] Arian, M. (2011) Basement Tectonics and Geology of Iran. AsarNafis Press, Qum, 300 p.

[104] Shahabpour, J. (1994) Post-Mineralization Breccia Dike from the Sar Cheshmeh Porphyry Copper Deposit, Kerman, Iran. Exploration and Mining Geology, 3, 39-43. 